\title{
Comparison Of The U.S Tennessee Valley Authority And The River Basin Development Authorities In Nigeria
}

\author{
${ }^{1}$ Ebifuro Odubo, ${ }^{2}$ Eniye Mienye \\ ${ }^{1}$ Department of Geography and Environmental Management, Niger Delta University, Wilberforce Island, Bayelsa State. \\ ${ }^{2}$ Bayelsa State Polytechnic, Aleibiri, Bayelsa State \\ DOI: 10.29322/IJSRP.10.11.2020.p10749 \\ http://dx.doi.org/10.29322/IJSRP.10.11.2020.p10749
}

\begin{abstract}
The role of the River Basin Development Authorities is to bring about rapid economic development to Nigeria by harnessing water resources in various regions to promote agricultural development through large scale irrigation projects and general water management. Though various achievements have been recorded, evidence reveal that RBDAs in Nigeria have not led to appreciable economic development. Using a comparative approach, this study reviewed the TVA as a successful model and novel concept in river basin project to compare the RBDAs in Nigeria. The study concluded that lack of institutional interfaces between state structures and RBDAs is responsible for poor organization of the RBDAs. The study also recorded variety of other factors also affecting the RBDAs in accomplishing its objectives.
\end{abstract}

Index Terms- Tennessee Valley Authority, River Basin Development Authority, decentralization, regionalism

\section{BACKGROUND TO THE STUDY}

$\mathrm{O}^{\mathrm{n}}$ ne of the Key Objectives of economic planning is the correction of imbalances in regional development - rapid economic development of backward regions. The idea of creating River Basin or Water Authority in Nigeria evolved from the success of the Tennessee Valley Authority in the United States of America in the early 1930s, with the intent of developing the relatively backward Tennessee region. Therefore, the role of River Basin Development Authorities in the economic development of Nigeria is to undertake the development of water resources in various regions, promote agricultural development through large scale irrigation projects and general water management germane for Nigeria's rapid national socio-economic development. Though various achievements have been recorded (Danladi and Naankiel, 2019), majority of studies reveal river basin development authorities have not led to appreciable economic development. Thus, the need to understand the causes of failures in river basin projects in Nigeria have continued to agitate the mind of researchers. Danladi and Naankiel (2019) adopted a multidisciplinary approach of using both primary and secondary sources to show that corruption, mismanagement, politicization of agriculture, poor funding and insecurity are responsible for the poor economic development of river basin in Nigeria.

Okeola and Balogun (2017) used exploratory reviews of Federal Government of Nigeria's gazettes, agencies reports, intergovernmental documents on water resources policy as primary data source and publications by academia to identify contradictions and overlapping statutory responsibility constitutes policy implementation impediments to effective and efficient river basins operations. Akindele and Adebo (2004) adopted a retrospective analytical method with focus on the Owena River Basin Rural Development Authority. The study concluded that political interference is the bane of river basin success in Nigeria. These studies in Nigeria did not take into cognizance comparison of the TVA as a successful model and novel idea of river basin project as against the River Basin Development Authority's in Nigeria. Based on the above short comings, this study will attempt to provide answers to the following questions;

1) What is the regional context guiding the preparation of regional plan and the country policy towards regional planning of the TVA (USA) and RBDAs (Nigeria)?

2) What is the rationale for the establishment of the TVA and the RBDA's and its implication on the success of river basin projects?

\section{CONCEPT OF REGION}

As recorded by Vulkovic and Kochetkove(2017), the term region does not have a clear definition. Due to its multifaceted nature, it certainly has natural, cultural, economical, political and social dimension. At the same time, this term occupies a wide range of phenomena from small parts of countries to huge continental interstate formations. Regions have been considered differently by different researchers belonging to various disciplines. And while doing so these researchers tended to conceive regions in the context to concepts pertaining to their own disciplines. An idea of this variation in thinking and conceptualization of regions can be had by looking at what a sample of thinkers have to say in this regard.

UNCRD (2013), defined a region according to the issues being addressed. And there are different scales in both governance and issues of concern.

Oludere (2011), streamlined the numerous views of scholars on definition of region into two: objective and subjective views. The objective view according to the researcher, claim that a region is a real entity that can be physically identified and mapped. This view follows Henderson (1905) cited in Oludere (2011), that Posit the entire world can be divided into natural regions on the basis of four criteria namely; land configuration climatic conditions, vegetation types and natural resources. Equally, Goh Cheng-Leong and Adeleke (1978) cited in Oludere (2011), divided the whole world into 12 climatic regions based on: 
distinct latitudinal locations, climatic conditions, natural vegetation types and natural resources.

The subjective view consider region as an instrument for spatial segregation. Thus Oludare (2011), posit that regions are descriptive tools, defined according to particular criteria, for particular purpose. There can be many regions as there are criteria to define them.

DRD (1984) defines region as any subnational area that a country calls a region for purposes of planning or development. A region may also comprise parts of more than one country.

\subsection{Planning Region}

According to Chandna (2016), the planning region is an areal unit which is deemed fit for the purpose of regional planning and is a distinctive area in itself while being part of the spatial whole. Its relationship with the spatial whole could be best compared with the relationship of any sub-system of the human body such as the nervous system or digestive system or any other sub-system with the body whole. As each sub-system of human body is distinctive in itself and yet is not independent of the body whole, in the same way, a planning region is a distinguishable unit of area due to its own characteristics and yet does not exist in isolation from the spatial whole. Nothing can happen in a region without affecting the other area in the same way as anything going wrong with the digestive system affects the functioning of the whole body.

It implies that a planning region is a region in which the whole is related to the part in the same way as the part is related to the whole. It has the functional unity of the kind as displayed by a city region say the Port Harcourt (Nigeria); it has the similarities of problems and the potentialities of the kind as displayed by say the Niger Delta (Nigeria); it has the economic unity of the kind as displayed by say the ECOWAS sub region(West Africa); it has the social unity of the kind as displayed by say the Yorubas in the South West of Nigeria. Thus, a planning region is a self-created living organism having a life line which not only does support the life in the region but also radiates unifying forces that enable the region to be a unified regional space so as to facilitate the practice of regional planning (Chandna, 2016).

Such a conceptualization of planning region implies that a planning region should have the following characteristics: neither too big nor too small a size; flexibility of its boundaries; contiguity and compactness of its shape; natural cohesion; economic harmony; social harmony; functional unity; similarity of its problems; regional consciousness and administrative convenience

\section{CONCEPT OF REGIONAL PLANNING}

In the literature, several definitions of regional planning have been made. Accordingly, regional planning is imperative to the economic development of a region (Srinivasan, 1971). In such conceptualization, there is a strong belief that regional planning secures the best conditions and possibilities for an all-around development by minimizing and ultimately eliminating interregional and intra-regional difference.

According to OECD (2000), attention to problems on a regional scale provides a means of counteracting centripetal forces inherent in economic and technological development which tend to widen the existing disparities between one part of a country and other.

Regional economic planning is best viewed as a component of national economic planning and overall national economic policy (Glickman, 1977). This follows that Regional Planning is planning for development of a region which is demonstrated on geographical or economic consideration and is designed for the development of the resources of that region (Tungare, 1969). In such a concept, the plans are conditional because they give physical situation, natural resources and the levels of socioeconomic development already reached and that the plans are drawn up for the development of the potential of the region.

According to Chandna, (2016) regions operates in a distinctive environmental setting characterized by the comprehensiveness of regional space. In addition, it has a distinctive scale of operation. However, the scale at which its actions take place cannot be standardized. It may vary both in time $\&$ space. Furthermore, it is distinctive in the sense that it is a coherent corpus of thought and action translated into regional reality. According to Chandna (2016), each region or a planning unit is unique and as such each regional plan too has to be of its own type. It means that there can be no standardized regional plan which could be applicable even to similar type of physical/natural region say basin regions in different basins in the same country. Each regional plan has to be guided by regional context of its own as well as by the planning policy, which may vary from country to country.

The planning policy of a country becomes the starting point of any regional planning exercise as it provides an impulse to the plan. Therefore, no regional plan could be studied and evaluated without the preliminary understanding of the problems associated with the starting point i.e., the regional context and planning policy of the concerned country. That will determine the objectives, the design of the plan and the planning process. The context in which each regional plan has to be prepared necessitates different approach to regional planning in each such case although with the common objective of cultivating habitability in the regions of human occupance.

As observed in the foregoing paragraph, each region or a planning unit is unique as such, each regional plan has to be of its own type it means that there can be no standardized regional plan which could be palpable even to similar type of physical/natural region. Each region plan has to be guided by regional context of its own as well as by the planning policy of the country, which may vary from country to country. However, this conceptualization of regional planning, will be used in this work.

\section{SYSTEMS THEORY}

David Easton "s system theory of 1965 is a system analysis of political life (Sorka (2007). Furthermore, Sorka (2007) affirms that the theory views organisation as having parts closely related and linked to each other and having a give and take relationship among the parts working to ensure stability of the organization. As a consequence, the parts carry out functions efficiently and effectively to ensure continuity and survival of the system. The theory further implies that the environment has a crucial role in determining organizational performances. It seeks to find out which aspects of the social system influences organizational 
performance overtime thereby enhancing the ability to account for change and development.

David Easton who adopted system theory to administration in 1953 conceived that a political system could be seen as delimited (with boundaries) and changing.

The System Theory arose out of the need to provide explanations on aspects of workings of organization not covered by the traditional classical and other theories of administration. The system as a concept is derived from the biological sciences meaning a whole with interrelated parts. Ogunbaremu (2004) views the system approach as exhibiting features of holism or synergy hierarchy of parts which work harmoniously for the attainment of goals of the higher system and are equally affected by the alteration in one of the parts. The model uses as its major unit of analysis the political system in which political life is viewed as a system of behavior, Political systems are defined by Easton as a set of interactions, abstracted from the totality of social behaviour, through which values are authoritatively allocated for a society. In this definition, there are a number of assumptions that lend direction to systems analysis. For one, the emphasis is on interaction as a variable.

Interaction may take place between individual actors, institutions or actors and institutions collectively interacting with others. Easton recognized that there was no single way of conceptualizing human behaviour, which could properly encompass the variety and behaviour therefore, must be quite general and broad in nature. A system is presumed to be analytically distinct from its environment. Although an analytical distinction is made between the system and its environment, the system is open in varying degrees to influences from the environment. Indeed, the nature of environmental influences and the ways in which the system responds to them is one of Easton's major concerns. In separating a system from its environment, however, we refer symbolically to the system boundary. The nature of systematic boundaries, how they are defined and their degree of flexibility or rigidity are major problems facing systems theorists. If we assume that systems are susceptible to varying degrees of influence from the environment, and that systems may affect their surroundings, we must make reference to the inputs, outputs and feedback variables.

The main assumptions of system theory were:

(a) Inputs - The system theory assumes that there exist inputs made in the organization from the environment and sometimes from within the organization.

Here the demand for the provision of certain facilities by the public would be explained as inputs into the government or its agencies. It could also mean the public making inputs in terms of advice for government agency to succeed achieving set goals. Provision of resources by government for execution of planned programmes is also considered as inputs.

(b) Conversion Process - The system theory believes that inputs made into an organisation need to be processed and converted as outputs. The manner in which the conversion process responds to the inputs depends on previous antecedence and inclination to follow the antecedence. The central issue here is the management willingness to commit allocated resources to planned programmes. (c) Output - This connotes rendering services or executing desired programmes. In public organisation it may also involve the decision and policies made by the Government.

(d) Feedback - The system theory assumes that the organisational system would send back information into the environment and also receive further inputs as response from the environment. Thus, execution of programme or provision of certain services by the organisation based on demand (input) from the environment would further receive (feedback) responses in term of acceptance, rejection or demand for improvement from the environment.

\subsection{Systems Approach to Regional Management}

The forms and methods of management of a social or economic system are always largely determined by the goals, structure, and functions of this system. The management system or managerial bodies reflects the characteristics of the system to be managed and is itself an integral part of it (Knop, 1979)

A regional system is characterized by the social and economic units acting as part of this system, their roles and interrelations. The main functions of a regional system occur in: - Social services to provide health care, education and information: - The circulation and distribution of goods and financial funds; - The protection, conservation, and development of the natural environment and available natural resources.

These programmes or services rendered by the management system or organization are the inputs made into the regional system (Knop, 1979)

These activities are performed in specialized units factories and plants, transportation enterprises, social service utilities, institutes. and settlements and these constitutes the component parts of the system.

A regional system is also characterized by a wide variety of social and political groups, whose nature varies in accordance with the national sociopolitical structure. Each group in any national setting, however, represents an individual set of social, economic, and political interests in the region. The interaction among these groups and their differing levels of influence determine the goal-setting process and priorities for the future development of that region (Knop, 1979).

Systems elements of regional management include;

Managerial bodies dealing with regional planning and management, such as Federal, state, county, and city governing parliamentary bodies; Governing agencies; Management of nationalized enterprises; - Management of cooperatives; Management of private enterprises; Management of social service units.

The management of regional development dwells on the degree to which these managerial bodies interact and to which it can be guaranteed to streamline all activities in the direction of a complex, unified, and harmonious development of the region. This requires, in many cases, a certain centralization of regional management functions and the creation of specialized organizations to perform these functions.

\section{CONCEPT OF DEVELOPMENT}

According to Omuta and Onokerhoreye (1994), there is no universal definition of the term development. Some definition is 
based on economic criteria, some on social conditions, while others are based on political considerations. Other researchers like Chandna (2016) have included aside the list above, political consideration, historical and geographical views.

The economist view development in terms of economic progress expressed in terms of enhancement in the standard of living of people in general, or enhancement in general productivity level per capita income, efficiency of a worker and overall improvement in quality of life in general (Chandna, 2016). The economist concept of development revolves around economic growth, economic planning, and economic policy. Most economics are of the view that if an economy is growing, say at the rate of 3 percent per annum then the general socio-economic well-being of the population will improve. (Omuta and Onokerhoreye, 1994). However, the economic growth and development can only come about through good economic planning and economic policy.

Sociologist, on the other hand believe that economic development was of little relevance in the absence of social development. According to Deutsh (1971) as cited Omuta and Onokerhoreye (1994), development encompasses numerous processes of change which are frequently associated. These include spatial mobility, occupational changes, changes in roles expectations, needs, behavior, associations, family, marriage etc. consequently, the societies have been classified by the sociologists into folk, agrarian, industrialists, on the basis of respective social structures. The two most significant parameters of measuring social development include quality of life and social justice (Chandna. 2016). The quality of life in this context is measured in terms of social harmony and social cohesion and social justice that has its focus on equal rights and opportunities to all segment of a society.

The political scientists' conceptualization of development has its focus on political context, each political setup, according to Chandna (2016), shall have its own political structure and hence political economy. Tis justification is seen in the increasing role of government not only as promoter but also as the principal planner. Thus, power structure holds the pivotal position in political scientists conceptualization of development.

The geographer conceptualizes development as much more comprehensive. The geographer considers development in terms of regional development covering economic progress, social advancement, political development and environmental preservation (Chandna, 2016). Economic progress can usually be measured by progress in; standard of living, per capita production, per capita consumption, degree of manpower utilization, extent of diversification of economy, etc.

The measures of social advancement lie in quality of life, social harmony, social cohesion, social justice, etc. Political development of a society finds its experience in the degree of decentralization of power, administrative efficiency, and degree of participation of the general masses in welfare activities. Environmental Conservation usually refers to the state of ecological balances and the state of environmental degradation in terms of soil erosion atmospheric pollution, water contamination, wildlife conservation, noise pollution, preservation of biodiversity, etc. apart from the unique synthesis of physical, social and economic development conceptualize by the geographer, the main thrust of geography, however is on the spatial perspective of development.

All of the above definitions of development are quite relevant to the regional analyst and planner who is primarily concerned with the spatial aspect of development. The regional planner/analyst is interested in how economic, development, social development and political development, etc. are reflected in space. This study will dwell on the geographic concept of development due to its all-encompassing nature.

\subsection{Theories of Development}

Within the discipline of Economics, there is a subcategory development, which is somewhat new. It seeks to apply identified tools and approaches to the economic, social and institutional aspects of developing countries in order to achieve improvements in the standard of living (Todaro 2000) cited in (Shareia, 2015). The focal point of this kind of economics is the economic condition of developing countries regarding these matters and the development of policies that improve a nation's position economically, socially and institutionally.

Theories of Development were revitalized by happenings in the mid-20 $0^{\text {th }}$ century when decolonization occurred and the economic disparity between European and underdeveloped nations became obvious. Others believe that it is more accurate to evaluae economics as a general provider of organized systems (Todaro, 2000).

Consequently, social, economic and political aspects are included in theories of economic development, which apply different models related to different key concepts (Martinussen 1997; Roberts and Hite 2000) cited in (Shareia, 2015). One effective method through which the differentiation between various theories can be recognized is by their classification, based on the primary concept each theory identifies as the driver of economic development, whether internal or external. Several definitions exist for development and offer different focal concepts. For instance, the regional approach and the integrated approach has a primary concept of harmonious development of man and natural resources implemented at a regional level. While the industrial model of growth is of the view that development involves a transformation of a traditional or pre-capitalist Social formation to a Capitalist Social formation, with the type of technology and social organization that characterized the advanced industrial and post-industrial Nations.

However, the study of these different approaches is very important to the development planning of a region, because, the rationale for establishment of managerial bodies such as the River Basin Development Authorities in Nigeria and the Tenessee Valley Authority in USA is based upon.

\subsubsection{Industrial Model of Growth}

This model is of the view that development involves a transformation of a traditional or pre-capitalist Social formation to a capitalist Social formation with the type of technology and Social organization that characterized the advanced industrial and post-industrial nations (Chew and Lauderdale, 2010). Details of such views on development can be found in the works of W.W Rostow (Rostow, 1962). The theory implies that 3rd world countries which are linked to the world capitalist system through colonialism and since independence through loans and Multi- 
National companies and the growing indigenous capitalist should adapt the technology of the developed capitalist countries like Japan and that this will make for their economic growth. Several Scholars have in recent time criticized the views of development implicit in the classical theories (Chew and Lauderdale, 2010)

\subsubsection{Regional Approaches to Development}

A regional approach to economic development has been widely recommended (Cole, 1989). It is sometimes seen as a strategy for scarce resources in such a way as to produce both economies of scale and external economies. The regional approach may also be recommended in nations featuring significant spatial differences in resource endowments, population characteristics, and cultural heritage (Oxendine and Disinger, 1989). In such cases it often appears appropriate to tailor special development programs to the unique attributes and requirements of each region. A regional concentration of resources is also appropriate where one or several areas of a country lag significantly behind the rest (Oxendine and Disinger, 1989).

Another theme of economic development is the integrated approach to rural development. Proponents of this approach define rural development broadly. Whereas increases in agricultural production and especially in yield, constitute the centerpiece, many other aspects of the rural sector are considered to be vital to those ends (Oxendine and Disinger, 1989). Rural industry, infrastructure, education, health and the institutional structure of local government are viewed as crucial components of development argue that because the components of the rural sector interact in a circular and cumulative fashion, an efficient approach calls for planning and administering the delivery of component services in coordinated manner(Oxendine and Disinger, 1989).

One practical problem that has faced the regional approach has been the delineation of appropriate regions for development. The regions quite often have been defined along geopolitical boundaries, with the economic rationale as secondary consideration. However, in the case of, taking a river, its principal tributaries, and the accompanying watershed as the developmental focus, the definition of the region is more clear-cut and certain political factors are therefore more easily eluded (Oxendine and Disinger, 1989). Because the river is a prominent factor in ecology of the watershed, a river basin approach also makes it easier than otherwise to ensure that regional development provides for longterm ecological protection.

Finally, the river basin itself and the obvious ecological interrelationships provide an intensity of focus for planning and administration that area likely to be achieved by projects operating on a national scale. It has been observed that whereas village-level, pilot integrated development projects have often proved relatively successful, disappointment has more often been the case at the national level (Ruttan, 1975). An important reason for this disparity is that planning and coordination are carried on at the level of the national government, while implementation takes place in widely disparate regions. The needs at the grass roots may be dimly perceived at the centre, while the ideals and enthusiasms of the planners are diminished as they travel the geographic miles and cultural "light years" to the points of implementation (Oxendine and Disinger, 1989). The village is probably too small in scale for the creation of machinery to plan and successfully integrate the components of development, and the national scale is too large. A regional scale is probably more appropriate in many cases, a region defined by ecological conditions rather than political boundaries may be the ideal.

\subsubsection{Decentralization}

Decentralization is a form of administrative organization and is defined as an administrative method for the rule of the region, where the central authority transfers some of its legislative, judicial and executive powers to the regions. The constitution establishes the relationship between the state and the regions so that the state exercises sovereignty over it through its basic functions of maintaining security, justice and defense (World Bank, 2001). It can also be said that decentralization is an act by which the central government transfers authority and responsibility formally to actors and institutions at a lower level in a political, administrative and spatial hierarchy (Agrawal and Ribot, 1999). Moreover, transfers a large part of the responsibility for planning and the management then collecting and distributing money from the central government to subordinate or semiautonomous government organizations that include field units of ministries, units or sub-levels of the government, Semiautonomous public authorities or units of regional or functional powers.

Decentralization can also be defined as the situation correlating with the participation in decision-making given to the lower administrative levels without ignoring the right of the central authority to make the decision power and powers between the authority and other independent institutions existed in different regions and communities (UNDP, 1999). This means that decentralization is to activate the role of regional and local authorities by assigning administrative and developmental planning tasks that increases their effectiveness and enhances their role in carrying out their responsibilities and powers in a manner that integrates local people into local development processes and ultimately leads to their success.

Many countries adopt system of decentralization at the level of general government administration to achieve optimal levels of public participation in the public affairs of the country (UNDP, 1999). The monopoly of power in the center cannot produce rapid and significant progress and grant wide powers to regions, cities, municipalities and communities that enable people to participate directly in Management of governance processes and merge into the national, political and economic development effort (UNDP, 1999).

Decentralization will preserve the specificities of the ethnic, cultural and reconciliation regions and helps to eliminate the hotbeds of tension resulting from the central imposition policies that negate the self-specificities of local communities, which promotes peace and national coexistence and facilitates merge and participation.

\subsubsection{Grassroots Development}

The term grassroots imply that planning and decisionmaking institutions are located within area that is to experience the development, and that local persons and local institutions will be incorporated in some fashion into the planning and delivery process (Oxendine and Disinger, 1989). This is also the meaning of the term participatory development. Both terms imply that a 
development cannot succeed without the enthusiastic cooperation of the people who are to experience development.

\subsubsection{Regionalism}

Odum, describes regionalism in the following 4 points (George, 1955). The first is regionalism as a science. From the various fields of geography, ecology, biology, history, economics, sociology, etc. Natural sciences and social sciences, basic research must be conducted on the inter-functional relationships concerning man and resources, region and culture, physical environment and cultural environment, etc and the collected data analyzed, interpreted and used and through this "region" that allows for the cooperation and arrangement of the above sciences must be selected. Regionalism is, consequently, an integrated science. The second is regionalism as American's frontier. The early period of America's development was as it's name implies, a natural frontier. However, the new frontier of today must be a frontier with a social and cultural meaning. Early frontier involved the exploitation and conquest of nature but new frontier means the development and conservation of nature. Consequently, a planning region calls for a region that can discover a new balance and equilibrium through the redistribution of population, wealth and opportunity. The third is regionalism as a means and technique of administration. Regional development encourages decentralization and moreover since development planning, temporally and spatially, is flexible in character, development administration demands a special technique. Regionalism is an answer to this. Therefore, a planning region must correspond to this technique. The fourth is regionalism as a motive and goal. Development planning must activate the region's growth and stimulate their desires to positively participate in development activities. Due to this very fact, democratic ideas must first be realized, and this requirement is found in regionalism itself. These are the 4 points on regionalism by Odum(George, 1955). The region that he conceived as the object of regional planning ultimately as a component part of the nation and the regions have neither competition nor dissension between them. He asserted that development planning together with the goal of the region's inhabitant's welfare as do contributes to the prosperity of the U. S., so the Federal Government should grant leadership, equity subsidies, scientific research, expert guidance, research grants, technology and personal interaction to each region. In this way, Odum viewed the region as a whole society.

\section{THE REGIONAL CONTEXT GUIDING THE PREPARATION OF THE REGIONAL PLAN AND THE COUNTRY POLICY TOWARDS REGIONAL PLANNING}

The systems approach to complex regional development is said to be made up of two aspects. One is the embedding of the region in national development and the other, a determination of the objectives of regional development and their breakdown into related sets of sub-objectives and operational activities for implementation and control. What this simply means is that, the planning policy of a country becomes the starting point of any a regional planning exercise as it provides an impulse to planning. Therefore, no regional plan can be studied and evaluated without the preliminary understanding of the problems associated with the starting point i.e., the regional context and planning policy of the concerned country. That will determine the objectives, the design of the plan and the planning process.

The foregoing formulation is in tune with the conceptualization of Chandna (2016), who pointed out that there are three ways in which regional planning distinguishes itself from other types of planning. Firstly, regional planning operates in a distinctive environmental setting characterized by the comprehensiveness of regional space. Secondly, it has a distinctive scale of operation. The scale at which the actions take place cannot be standardized. It may very both in time and space. Thirdly, it is distinctive in the sense that it is a coherent corpus of thought and action translated into regional reality.

\section{THE REGIONAL CONTEXT GUIDING THE PREPARATION OF REGIONAL PLAN}

\subsection{Tennessee Valley Authority (TVA, USA)}

At the beginning of the 1930's, the USA was suffering from an economic depression that affected all aspects of national life: political, economic, and social. Unemployment was widespread. The situation was aggravated by the many farmers who, having lost their property migrated to the urban areas. Living conditions for a sizeable proportion of the population were very poor. Even in such conditions the Tennessee Valley was one of the poorest regions from practically all economic and social aspects:

- The per capita income of the population in the region as a whole was only $45 \%$ of the national average (\$168)

- $\quad$ More than half of the 3 million people were employed in farming, and farm incomes were low. Crops suffered from an uneven climate, endless rain alternating with extremely dry periods. out of a total of 14 million acres of open land about one half was abandoned or severely damaged by erosion

- Only $12 \%$ of the labour force were employed in manufacturing as compared to the national average of $22 \%$

- Almost $8 \%$ of the population were illiterate and the labour force was generally unskilled or semiskilled. People suffered from malnutrition, pellagra and malaria.

- $\quad$ The Tennessee river, the fifth largest in the United States by flow, carried only $32,100,000$-ton miles in 1933 . The huge potential from hydroelectric power production was practically unused; the installed generating capacity was less than 500,000KW.

- $\quad$ Frequent destructive floods were a disaster for the people and the region (the flood in 1967 at Chattanooga, Tennessee, caused damage amounting to approximately $\$ 500$ million). 1933, although the provided the regions greatest opportunity, it was the source of the scourge of the land.

- Malaria scourge in the region

However, the above conditions present in the Tennessee Valley Region formed primary goals that led to the establishment of the TVA.

The TVA act was the document that defined the principal objective to the establishment of the TVA. Going by the act, the development of the Tennessee and its tributaries will improve 
navigability and control flooding. Flood control would be achieved by the construction of dams, water reservoirs, and channels. These facilities together with the construction of power station, power structures, and transmission lines would be used to achieve hydroelectric power production. The development of the TVA itself was expected to be the basis for achieving:

a) The development of agriculture in the valley, by water supply and the application of fertilizers,

b) The development for fertilizer production in the valley to supply local agricultural needs,

c) Reforestation of the valley and development of recreation facilities.

The combination of these objectives makes it clear that from the beginning the overall goals of the Tennessee Valley Authority was the unified, multi-objective development of the Tennessee Valley.

\subsection{River Basin Development Authority (RBDA, NIGERIA)}

The establishment of the various River Basin Development Authorities in Nigeria started in a series of agricultural development strategies put in place through different agricultural reforms/policies and programmes. The River Basin Development approach is a realization in the 70's by the Nigerian Government that the strategy of direct agricultural production was not yielding the desired result. So, there was gradual shift to an agricultural development approach which involved the adoption of an integrated rural strategy (Olayemi, 1998) cited in (Ugwu and Kanu, 2012), Under this strategy, rural development is seen from a holistic perspective with agricultural development problems being only part of a larger rural development concern. This prompted the government, to embark on multipurpose rural development programmes. Aside the River Basin Development Programmes, others include the Agricultural Development Projects (ADP's), Food, Roads and Rural Infrastructure (DEFRRI), the National Agriculural Land Development Agency (NALDA), Operation Feed the Nation (OFN), Green Revolution (GR) etc.

In 1973, two basin development authorities were established. These are the Sokoto-Rima and Lake Chad Basin Development Authorities. The preamble of the law establishing the two RBDA's assigned the following objectives to the RBDA's to be accomplished most expeditiously for revitalization of the society and economy of Sokoto-Rima Basin, the Lake Chad basin and the country in general. Firstly, to improve the navigability in the region with a view to providing low cost transportation of raw materials and manufactured goods. Secondly, to provide foolproof flood control measures, loss of soil, crops, property livestock and life. Thirdly, to initiate rural extension services. Fourthly, to initiate adequately proper steps to ensure proper use of marginal lands in the region. Lastly, to ensure sustainable food production in Nigeria particularly following the droughts of the Sahelian region.

In 1976, eight more River Basin Development Authorities were created bringing the number of RBDA's in the country to ten. These eight RBDA's came into existence through Decree number 25 of 1976. An additional RBDA was created through Decree number 37 of 1976, bringing the total number of RBDA's in the country to eleven. During this period, the country was experiencing oil broom following the discovery of oil in the country. However, the oil broom came with sudden and unexpected wealth which seriously undermined the status of agricultural production and regrettably, succeeded in creating utter neglect for and relegation of agriculture to the background (Akindele and Adebo, 2004). As reported by Bamisaye (1985) and cited in Akindele and Adebo (2004), the declining rate of agriculture which was about $7.8 \%$ between 1970 and 1974 had reached an intolerable $1 \%$.

Other reasons for establishing RBDA particularly in the Niger Delta region, was due to environmental degradation brought about by exploitation of oil and gas in the region.

Going by the law establishing the Basins, it is expected that;

a) There will be improved agricultural development through provision of water for irrigation (to ensure all-year farming) fisheries projects, mechanized farming and livestock development.

b) Improvement of navigation, hydro-electric power generation and encourage the establishment of industrial complexes that could bring about privet and public sectors in join business partnerships.

c) Construction of dams of varying sizes to compound water to achieve objective (a) \& (b)

d) Flood and erosion control will also be achieved through the construction of dams.

e) Pollution control.

The objective of the programme was later extended to other areas most importantly to production and rural infrastructure.

In 1981, under the military leadership of Mohammadu Buhari the eleven Basin Authorities were metamorphosed into eighteen authorities and was redesigned as Basin and Rural Development Authorities with one serving the purpose of each state and one for Ogun and Lagos state combined.

The main goal and objective are the same as outlined in the 1976 law establishing the eleven RBDAs. However, the increase of the RBDA's from eleven to eighteen was aimed at decentralizing the authorities and bringing her functions and activities closer to the rural populace.

However, the restructuring of the RBDAs did not last as a new regime reverted it back to the previous eleven. The government also stripped the RBDA's of their full embracing functions except the provision of water resources.

\section{PLANNING POLICY OF THE COUNTRY}

In the course of regional planning, each regional plan has to be guided by the regional context of its own. These include environmental peculiarities and as well as the socio-economic and political development in the region. However, the planning policy of the country will also serve as a guide to the regional plan. The planning policy of the country will determine the objectives, the design of the plan and the planning process. This section will consider the country policy that have defined the development of TVA.

3.5. Tennessee Valley Authority (TVA, USA) 
The creation of the TVA followed the planning policy of the United States as at that time. From literature, the planning policy of the United States prior 1930's, was the building up of military strength. This became critically important in 1916, during World War I prompting Congress to pass the National Defense Act, authorizing the construction of nitrate plants, a process for which abundant electric power was essential. However, in 1917, President Wilson chose the Muscle Shoals site for two nitrate plants, and a dam (Wilson Dam) to supply the hydroelectric power to operate them.

During the period of 1933 to 1935, President Franklin Roosevelt enacted the New Deal policy. It was a series of programs, public works, financial reforms, and regulations embarked upon in the USA. It responded to needs for relief, reform and recovery from the Great Depression that affected all aspects of political, economic and social life of the USA beginning from the 1930s. Concern for food productivity is shown in the Agricultural Adjustment Act which offered farmers subsides in exchange for limiting their production of certain crops.

Also, of concern is the scourge of malaria, which was reported as 3.7 deaths per 100000 Americans in 1933(Sledge and Mohler, 2013). Of this record the Southern part of the USA which comprises the Tennessee region is most affected. Following the enactment of Agricultural Adjustment Act, it will be possible for the acquisition of artificial impoundments along the Tennessee river and its tributaries of notorious mosquito breeding areas. This policy will also help in the relocation of people from such areas after acquisition.

The country problems that led to establishment of the TVA can summarily be stated as;

1. The economic crises of the 1930s, which provided the impetus leading to the creation of the TVA

2. Participation in world war II, which greatly increased the need for electric power

3. Rapid post-war economic development, which stimulated demand for greater power production by the TVA

4. National trends in environmental control in the 1960s which initiated the changes in TVA to develop recreation, demonstration and conservation facilities.

5. Present energy crisis, which causes the TVA to greatly increase the energy production and to search for new energy options

6. The devastating effect of malaria, in the south of the United States i.e. Alabama State, which was controlled by creation of TVA.

By the 1950s, the TVA has achieved the objectives of possessing a very important tool for regional development-cheap electricity in combination with waterways network and recreation facilities. This attracted private industries to the region, resulting in population immigration and the growth of new cities, etc. this led to the economic development of the region.

\subsection{River Basin Development Authority}

\subsubsection{Sokoto RBDA\& Lake Chad RBDA (1973)}

Some of the changes that led to the present Sokoto-Rima RBDA and Lake Chad RBDA goal structure include the following;
- When the war ended in 1970, Nigeria leaders adopted a policy of "No Victor, No Vanquish" and embarked on a process of Reconciliation, Reconstruction, and Rehabilitation aimed at rebuilding shattered confidence and re-engaging Nigerians in accelerated development of their country.

- $\quad$ The FAO and Michigan university studies drew attention for increased food production.

- The unexpected natural disaster, the Sahelian drought of 1972 - 74, which caused untold 0production setbacks and leading to local shortages of stapes like, yam, cassava, maize, sorghum, millet and cowpeas.

- The rapid urbanization fueled by rural urban migration and a large number of demobilized soldiers after the war.

- In order to re-engage many people in productive enterprises, farming was identified as a likely have for unskilled labour that was available then.

\subsubsection{The Eleven River Basin Development Authorities} (1976)

The main country policies that define the establishment of RBDA are,

- The attention given regional development in the third national plan. Prior to 1975 , regional planning received very scanty attention in Nigeria's development planning effort. This neglect of regional development planning which is not contained in previous national plans was identified as one of the main weakness of Nigeria's planning effort, hitherto which has been mainly focus sectoral and financial planning. The objective of this policy thrust is to ensure uneven development amongst the states in Nigeria and by extension, to reduce uneven development in the country.

- The creation of states in line with the policy on regional development planning.

- The various agricultural policy objectives that targeted nutritional requirement of the population, rural employment and institutional environment conducive to participation of private economic agents (Garba, 2000).

- The concern for food shortage expressed in various government policies and programmes such as Green Revolution (GR), Operation Feed the Nation (OFN) and National Accelerated Food Production Program (NADPP), Agricultural Development Projects (ADPs)

\subsubsection{River Basin Development Authority (RBDA. 1976)}

The major factor that influenced the development of the 1967 establishment of the RBDA was to accelerate agricultural development which has declined after the oil boom. This is to be achieved through dam construction, which will improve water storage for irrigation, rural development and improve navigation. The main country policies that define the establishment of the RBDA are

1) The 1975 third National Development Plan observed that one of the weakness of Nigeria's planning effort hitherto, has been its heavy emphasis on sectoral and financial planning. Therefore, its main focus during the planning period is to reverse this trend by paying great attention to regional development. The objective is to ensure even development amongst the states in Nigeria and by extension, to reduce uneven development in the country. 
2) The creation of states and LGA's which is considered to be the cornerstone of Nigeria's regional development policy. States and LGA's are considered important for the promotion of development.

3) In Nigeria, the concern for food shortage has been expressed in various government policies and programs such as Green Revolution (GR), Operation Feed the Nation (OFN) and National Accelerated Food Production Program (NADPP).

\subsubsection{River Basin and Rural Development Authority} (RBDA, 1983)

Some of the changes that defined the goal that structured the RBRDA in 1981 are;

- The rapid decline in agricultural production with large supply gaps with attendant rapid increase in food imports from $7.7 \%$ in 1970 to $10.3 \%$ in 1979 (Ugwu and Kanu, 2012).

- $\quad 4.0 \%$ of Nigeria's export was made by agriculture in 1980.

- Agriculture sector recorded a negative growth of $2.1 \%$ per annum in GDP according to the third national development plan (Ibietan and Ekhosuehi, 2012).

- $\quad$ To tackle these problems, the RBRDA in 1981, adopted some policies before it and came up with new policies.

- Promulgation of land use decree of 1978. Prior to its promulgation different land law operated among the regions of the federation and following the declining contributions of agriculture to GDP in the aearly 1970s experts observed that peasant agriculture was the problem to increased agricultural output.

\subsection{THE RATIONALE FOR THE ESTABLISHMENT OF THE TENNESSEE VALLEY AUTHORITY (TVA, USA) AND THE RIVER BASIN DEVELOPMENT AUTHORITY (RBDA, NIGERIA)}

\subsubsection{Tennessee Valley Authority (TVA, USA)}

In a regional system, the management of regional development dwells on the degree to which various managerial bodies interact to guarantee streamlining of all activities in the direction of a complex, unified, and harmonious development of the region. The establishment of the TVA followed a careful interaction of all the existing managerial units as characterized in a regional system by a wide variety of social and political groups, whose nature varies in accordance with the national sociopolitical structure. that results in output of the system, which culminated in decision and policies made by the Government.

The TVA model follows the integrated approach to rural development. In this approach resources, rural industry, infrastructure, education, health, and institutional structure of local government are viewed as crucial component of development. The TVA model has been recognized as an integrated development of a geographic region (Cole, 1989). From Franklin D. Roosevelt's 1933 message to U.S congress advocating for the creation of the TVA to the Authority's most recent Annual Report, a constant vision has existed of the possibility of utilizing public powers for the purposes of developing natural resources, fostering economic development, and enhancing the quality of human life, all within the context of a democratic, participative partnership among regional organizations, local government, voluntary associations and the people of the Tennessee Valley (Cole, 1989). The TVA idea according to Cole (1989) was held to involve the unified development of man and resources. Furthermore, basic resources were land (including minerals), water and people. The TVA approach called for the integration of these resources in a fashion that would achieve harmonious development of the whole that would enhance the well being of each of the parts (Cole, 1989). However, the TVA model has successfully utilized water resource from the Tennessee River to bring about development in the region. At the time of the TVA's inception in 1933, its service region was among the poorest, least developed, areas in the USA. By 1950s the TVA was well established both regionally and nationally. Within a period of 20years (1932-1952), several of its achievements had become known and had attracted attention beyond national territory (Chandna, 2016). Part of the success of the TVA, was the application of placed based policies by the government of the United States. Such policies according to Kline and Moretti (2013), have arguably become the de-facto industrial policy in the United States and are also widespread in Europe and Asia. Also as recorded by Yamamura and Masaaki (1984), during the great depression in 1929, business over-centralization resulted in power going to the centre, local business was choked and great losses were incurred by powerless municipalities due to remote control.

The TVA as part of its success story has also heavily emphasized on decentralization. As identified by Yamamura and Masaaki (1984), one of the guiding principles of TVA is decentralization. Its structure makes it unique among federal agencies in the USA. TVA is an independent agency and not part of any federal cabinet department. The TVA Act provides it with the administrative freedom to meet the special requirements of its programme and to adopt the methods of administration of successful private as well as public enterprise (Bos, 1990). All powers of the corporation are vested in its three-member Board of Directors, which reports to the President of the United States. The President, with the consent of the Senate, appoints the members of the Board to serve in nine-year overlapping terms of office. He designates one member as Chairman (Knop, 1979)

The purpose of the methods of decentralization is to provide greater opportunity for a richer, more interesting and more responsible life for the individual and to increase his genuine freedom and his sense of its own importance (Yamamura and Masaaki, 1984).

The congress of the United States established the TVA as a national agency, but one confined to a particular region. This provided an opportunity for decentralization. A limited region, it outlines drawn by its natural resources and the cohesion of its human interests, was the unit of federal activity rather than the whole region (Yamamura and Masaaki, 1984).

To make possible for citizens of the region concerned to hold decision-making power and participate positively in TVA, TVA's headquarters was established not in Washington but in Knoxville (Yamamura and Masaaki, 1984).

The concept of decentralization, also involves the trend, grassroots development. This approach was adopted in the 
establishment of the TVA in order to achieve tenable development. Thus, the implementation of TVA projects calls for the integration of highly specialized professional and technical land development through the unity of man and resources. These professionals and technicians do not only have a wide insight on matters outside their realm, but recognize the relative importance of their own work, and those selected are also able to evaluate the value of other work when compared with their own. Otherwise, the very fact of the highly specialized men may endanger the fulfillment of the common purpose of development through the unity of man and resources. Therefore, the TVA Board exchanges views with the professionals and experts, introducing specialized views on wider public interests - the welfare of the valley inhabitants.

With this TVA objective, professionals and technicians engage in the projects were able to expand their views and scope of their own specialty, and welcome interdisciplinary links with other fields. This is further extended to administrators, implementators, and the region's inhabitants. In other words, the unifies development of resources must become the common purpose of all the people and all the agencies of the entire valley, otherwise the objective if TVA would not be fulfilled.

Closely, related to decentralization, is concept of regionalism. As described by Odum (George, 1955)M regionalism is an integrated science and a means and technique of administration. Modern regionalism according to Yamamura and Masaaki (1984), rest squarely upon the supremacy of the national interest. They further propose the harmonization of the regional advancement with regional resources. The concern for supremacy of national interest distinguishes regionalism from sectionalism. To this end, the TVA toed the line of regionalism. For example, to create it, seven states did not unite to demand special privileges to distinguish them from the country as a whole, regardless of the ensuing consequences to the national welfare. A federal legislature itself created the TVA as an autonomous regional agency whose basic objective was to conserve the natural resources lying in the valley of the Tennessee and to develop those resources on conformity with broad national objectives and policies.

\subsubsection{River Basin Development Authority (RBDA, NIGERIA)}

The establishment of the RBDA in Nigeria follows the development theory of industrial model of growth. This theory is of the view that development involves a transformation of a traditional or pre-capitalist social formation with the type of technology and social organization that characterizes the advanced industrial and post-industrial nations.

This view follows an attempt to solve food supply problem in Nigeria by adopting a Western system of agriculture development. This entails the belief that the traditional system of agriculture must be eliminated and must be substituted with Western capital - intensive agricultural systems based on the use of dams, tractors, harvesters, fertilizers etc. to translate this development path into reality the Nigeria government established the various RBDA's.

However, it is obvious that Nigeria's attempt at solving her food and agricultural problems are based, not on carefully thoughtout plans, that build on existing strategies but on ad hoc plans and experimentations with River Basin Development Authorities. These are based on imported ideas and technologies which documented records show have not been very successful in Nigeria. For example, Modo (1983), in a research to examine the impact of river basin development authorities on Nigerian development authorities on Nigeria development, showed that the modern agriculture techniques led to submergence of old Maradun civilization. These techniques were not only recommended by F.A.O experts in its implementation but have also been influenced by F.A.O experts in its implementations. As a result, the Sokoto Rima Basin Development Authority which happens to be the case study here, imported machines, tools fertilizers etc. through transnational corporations. This imported strategies and technologies get progressively modified or abandoned with the emergence of new regime in a perennially politically unstable situation that has continually plagued the country. For example, the Babangida administration stripped the RBDA's of all their functions except water resources, despite the RBDA's obviously still struggling to achieve their goals.

Available and documentary evidence, Modo (1986), support the contention that, as with the indigenous Gungawa ethnic group of the Kainji dam site, the old agricultural practices of old Maradun met the food needs of the people and their neighbors prior to the creation of the dam. The people of old Maradun practiced complex surface irrigation method similar to what Sokoto-Rima River Basin Develoment Authority later introduced. The society of old Marndun was organized in such a way that its people regularly produced abundant and surplus food to the extent that they were supplying their surplus to cities like Talata, Mafara, Gusau and Sokoto. Indeed, many rituals and taboos existed which were believed to be essential for good annual yields. Elaborating title-taking and social stratification developed around and stimulate healthy competition for the production of surplus. Old Maradun culture thus revolved around hydraulic agriculture and surplus food production.

The RBDA model in Nigeria also adopted the integrated approach to regional development. This is evident in the goals that precipitated the establishment and modification of the various RBDA's in Nigeria. However, in Nigeria it has been observed that village-level integrated projects have often proved relatively unsuccessful. An important reason for this is that planning and coordination are carried out at the level of the Federal Government, while implementation takes place in at the grassroots. The needs at the grassroots may be dimly perceived at the centre.

The RBDAs also emphasized on the concept of decentralization. However, unlike the TVA, the RBDA was established as a national agency, but it is spread out in different regions of the country. While the government has a decentralization policy, little actual decentralization has happened (Anselm and Amusa, 2010). RBDAs are parastatals under the FMWR, established by law, and its operations guided by rules and regulations (Adeoti, 2014). By function (according to the Constitution of the Federal Republic of Nigeria of 1999), the executive implements laws and programs, the legislature formulates laws, and the judiciary interprets laws. By virtue of its creation, the RBDAs are part of the executive arm of government in Nigeria. Adeoti (2014) emphasized that this mode of operation of the RBDA breeds corruption and political interference. For example, as commented by one of the repondents in Adeoti (2014), "Some of the projects are not actually conceptualised by 
the River Basin [Development Authority]. You now have a member of senate or house representatives that comes from a certain constituency putting projects in the budget for you to implement, I mean, no study before, no planning before, you don't have a very clear conception of the project right from the word go, somebody just put it there for you [to implement". Furthermore, Akpabio et al. (2008) show that efforts at the CRBDA seem to be directed towards areas with less water problems (the lower part of the basin) rather than areas with acute water problems (the upper part of the basin). A possible explanation for this imbalance relates to corruption and the politicization of water projects. For example, the lower parts of the basin represent urban settlements which harbour the most influential politicians and top government officials. The ability to influence the location of government projects around their settlements demonstrates their influence and power-wielding capacity.

Also, unlike, the TVA the RBDA is established as an agency of the Federal Ministry of Water Resources. Though, the headquarters of the RBDAs are located in the regions, decisions are taken at the Federal capital in the ministry of water resources. The implications here is that, the citizens of the region are not part of the decision making.

The RBDAs also adopted the grassroots development approach. Similar to the TVA, the Nigerian model, calls for the integration of highly specialized professionals and technical land development through the unity of man and resources. In order to achieve the objectives of the TVA is expanded to include administrators, implementors and the regions inhabitants. However, in the case of Nigeria, the regions inhabitants are mostly left out, thus defeating the grassroots conceptualization of unifying development of resources for the purpose of all people. This is closely linked to the non participatory approach of top to bottom concept of development adopted by Nigeria, which does not involve inhabitants in decision making. A study by Adekunle, Oladipo, and Busari (2015) recommended encouragement of participatory irrigation scheme (PIM), after recording $78.3 \%$ of farmers in the Lower Niger Basin and Rural Development Authority, Kwara State, Nigeria lacked knowledge of irrigation techniques, $76.6 \%$ lack access to credit facility and $85.2 \%$ acknowledge poor response to farmers need by the Authority.

The RBDA, like the TVA dwell on the concept of regionalism. The establishment of the RBDAs by the various administrations in Nigeria laid emphasize on the supremacy of national interest as above regional interest. Obviously, the major goal of the various RBDAs is to harness the river resource from the various regions to bring about development in the regions and at the national level.

\section{SIMILARITIES AND DIFFERENCES}

\subsection{The regional context guiding the preparation of regional plan and the country policy towards regional planning of the TVA (USA) and RBDAs (Nigeria) \\ Similarities \\ - The primary goal is harnessing of water resource to achieve development \\ - Development is focused in a region \\ - The planning region is considered to be a river basin}

- The planning policy of both countries determine the goals of the TVA and the RBDAs. For example, in the USA during World War I (1916), it became critically important to build military strength. The Sahelian drought in parts of Nigerian and the Sahelian region precipitated the establishment of the Sokoto Rima and Lake Chad Basin Development authorities in 1973.

\section{Differences}

- The TVA constitute just a region while the RBDAs constitute the development of different regions.

\subsection{The rationale for the establishment of the TVA and RBDAs}

Similarities

- $\quad$ The TVA and the RBDAs follow the integrated approach to rural development.

- The TVA and the RBDAs both adopted the decentralization approaches to development.

- Both agencies, TVA and RBDAs toed the line of grassroots development.

- The concept of regionalism is adopted by the TVA and the RBDAs established in the region where the agencies differences are located.

Differences

- The RBDAs adopted the theory of industrial model of growth for less developed countries. This model was copied from the developed countries model such as TVA in USA and account for the not too successful nature of the RBDAs. The techniques and technologies of the TVA were alien to Nigeria.

- Though both agencies, TVA and RBDAs adopted the integrated approach to rural development, the TVA has been acclaimed to be very successful unlike the Nigerian RBDAs. This is due to the fact that the TVA was an application of place-based policies practiced by the United States government. In Nigeria, decisions are taken at the national level without considering the inhabitants of the region.

- Though both agencies adopted decentralization as their development policies. The TVA was established as a national agency confined to one region, whereas, the RBDAs are spread out in different regions.

- The TVA is an agency of the United States Government confined to one region, whereas, the RBDA is established as an agency of the Federal ministry of Water Resources. The implications is that decisions taken have minimal impact on the people.

\section{CONCLUSION}

- Lack of institutional interfaces between the state structures and the RBDAs is observed to be responsible for poor organization of the RBDAs

- Imported strategies and technologies that get progressively modified or abandoned with the emergence of new regime has continually affected RBDAs in achieving their goals. 
- $\quad$ The integrated approach to RBDA development has not been very successful due to the needs of the grassroots not considered at the centre.

- $\quad$ Due to lack of actual decentralization, RBDAs breeds corruption and political interference.

Though the Nigerian model adopted the grassroot approach, a noninvolvement of inhabitants of the region in decision making has affected the RBDAs in achieving its objectives.

\section{REFERENCES}

[1] Adayi, A. (2019) River Basin Organization in Nigeria. The case of the lower Benue River Basin Development Authority. Ph.D dissertation, Lisbon School of Economics and Management.

[2] Adeoti, O. (2014) An institutional analysis of the implementation of integrated water resources management in Nigeria. Ph.D Thesis, Cranfield University.

[3] Adekunle, O. A., Oladipo, F. O. and Busari, I. Z., (2015) Factors affecting farmers participation in irrigation schemes of the lower Niger River Basin and Rural Development Authority, Kwara State, Nigeria. S. Afr. Jnl. Agric. Ext. Vol. 43 n.2 Pretrria.

[4] Aggarwal, S. (2017) The need of regional planning.

[5] Agrawal, A. and Ribot, J. (1999) Accountability in decentralization: A framework with south

[6] Asia and west African cases. Journal of Developing Areas, Vol. 33, No. 4 (Summer, 1999). pp. 473-502 (30pages). Published by: College of Business, Tennessee State University.

[7] Akindele, S. T., and Adebo, A. (2004) The political economy of rural basin and rural Development authority in Nigeria: A retrospective case study of Owena - River Basin and Rural Development Authority (ORBRDA). J. Hum. Ecol., 16(1): 55 - 62 (2004).

[8] Akpomuvie, O. B. (2011) Breaking barriers to transformation of the Niger Delta Region of Nigeria: A human development Paradigm Journal of sustainable development, vol. 4, No.3; June 2011.

[9] Akpabio, M. E., Watson, M. N., Ite, E. U., and Ukpong, E. I. (2008) Integrated water resources management in the Cross-River Basin, Nigeria. International Journal of Water Resources Development, Volume 23, 2007 Issue 4.

[10] Alden, J. and Morgan, B. (1974) Regional planning: A comprehensive view, Leonard Hill Book Co., Bath.

[11] Alexeev, M., N. Avxentyev, and A. Mamedov, Fiscal decentralization and budget discipline in Russia's regions. 2015.

[12] Anselm, A. E. and Amusa, A. T. (2010) Challenges of agricultural adaptation to climate change in Nigeria: a synthesis from the Literature. Presented at an international conference on "enhancing Agricultural Adaptation to Climate Change", 27th July, 2010, Enugu, Nigeria.

[13] Andreeva, E. and N. Golovanova, Decentralization in the Russian Federation. Moscow: Center for Fiscal Policy, 2003.

[14] Awachie, J. B. E. (FAO, 1981) Seminar on river basin management and development. CIFA Technica Paper No. 8 retrieved from www.fao.org/docreep/order.htm on 08/08/2020.

[15] Barrow, J. C. (1998) River Basin development planning and management: A critical review World Development, Vol. 26, No. 1 pp. 171 - 186, 1998.

[16] Bos, R. (1990) Incorporating institutional and legal requirements. Retrieved from irawash.org/sites/default/files/Bos-1990-incorporatng.pdf on 08/08/2020

[17] Chandna, R. C. (2016) Regional Planning and Development. Kayani; publishers, New Delhi -110002.

[18] Chew, C. S. and Lauderdale, P. (2010) Sociology of development and the underdevelopment of sociology. In: Chew S. C., Lauderdale, P. (eds) Theory and methodology of world development. The evolutionary processes in world politics. Series. Palgrave Macmillan, New York.

[19] Cole, E. W. (1989) Integrated regional development. (ed) In: Oxedine, B. L. and Disinger, F.J (1989) Integrated regional resources management. Based on the experience of the Tennessee Valley Authority. TVA/WR/WQ - 89/3, Knoxville, Tennessee. December 1989.
[20] Danladi, A. and Naankiel, W. P. (2019) River basin development authorities and Nigeria's economic development since 1960 . The journal of the faculty of arts and Islamic studies, vol. 17/1, June, 2019/ ISSN: 0794 - 9316. PP. 52 -66 .

[21] Downs, L. M. (2010) Creating a different citizen: The federal development Tennessee Valley, 1915 - 1960. Phd dissertation, University of Alabama.

[22] DRD (Department of Regional Development). (1984) Integrated regional development planning: guidelines and case studies from OAS experience. Department of Regional Development Secretariat for Economic and Social Affairs Organization of American States in Collaboration with National Park Service-USDI, and U.S Agency for international development, Washington, D.C. January, 1984

[23] Easton, D. (1965) A system analysis of political life. New York. Wiley.

[24] Gana, A. B., Abdulkadir, I. S., Musa, H. and Garba, T. (2019) A conceptual framework for organization of river basin development management in Nigeria. European Journal of Engineering Research and Science, Vol. 4 No. 6 June 2019.

[25] Geddes, P. (1968) Cities in evolution (New revised edition), Benn.

[26] George, L. S. (1955) Howard W. Odum and American regionalism. Social Forces Vol. 34, No. 2 (Dec. 1955), pp. 101 - 106 (6 pages) Published by: Oxford University Press

[27] Glasson, J. (1980) Regional Planning and sustainability - towards integration in the UK and EU

[28] Glickman, N. J. (1977) The management of the Japanese Urban System: regional development and regional planning in posturer Japan. University of Pennsylvania, 361 McNeil Building/CR, Philadelphia, Pennsylvania 19174, USA.

[29] Ikporukpo, C. O. (1983), Nigeria's Regional Policies: Issues in Conception and Performance.Research for Development, Vol. 3, No.1 pp.63-75.

[30] Knop, H. (1979) The Tennessee Valley Authority: A field study. International Institute for Applied Systems Analysis, Australia

[31] Mackaye, B. (1928). New exploration: A philosophy of regional planning (New Edition in 1962). University of Illinois Press, Urbana.

[32] Modo, I.V. (1986) New Maradun - A Creation of Sokoto Rima River Basin Development Authority. An Examination of the Plc 12 and Impact of RBDA"s on Nigeria"s Development. PhD Thesis University of Jos Nagogo

[33] Ogunbaremu, O.A. (2004) Organizational dynamics Unpublished Lecture Notes Bensu

[34] Okafor, S. I., and Honey, R. (2004). Oil and Territorial Decentralization in Nigeria, African Geographical Review, vol. 23, pp.5-22. In: Agbola T. (eds), Readings in Urban and Regional Planning second edition, department of Urban and Regional Planning, University of Ibadan, Nigeria.

[35] Okafor, S. I. (2019) Regional Development Planning. In (ed) Agbola, T (2019). Reading's in urban and regional planning, Faculty environmental design and management. University of Ibadan, Nigeria.

[36] Okafor, F. C. (1980) Integrated rural development planning in Nigeria: A spatial dimension. In: Cashiers d'etudes africaines, vol. 20, no. 77 - 78, 1980 Pp. $83-95$.

[37] Okeola, O. G., and Balogun, O. S. (2017) Challenges and contradictions in Nigeria's water resources policy development: a critical review. International Journal of science and technology (STECH) Bahir Dar-Ethiopia, vol. 6(1), S/NO 13

[38] Oludere, A. (2011) Rural and Urban regional planning (EMT 425). Lecture Notes. Retrieved 10/08/2020 from unaab.edu.ng/wpcontext/uploads/2009/12/464

[39] Omuta, E. D. G., and Onokerhoraye, G. A. (1994) Regional development and planning for Africa. Benin social science series for Africa, University of Benin, Benin city, Nigeria.

[40] Oravee, A. (2016) A comparative study of the contribution of lower and upper Benue river basin development authorities to rural development. PH. D Thesis, Ahmadu Bello University Zaria.

[41] Oriola, E. O., and Alabi, M. O. (2004) Assessing River Basin system potentials to enhance sustainable irrigation farming operations and management in Nigeria. J. Environs. Res. Develop. Vol. 8. No. 3, January March 2014.

[42] Oxendine, B. L. and Disinger, F. H (1989) Intergrated regional resources management Based on the experience of the Tennessee Valley Authority. The Tennessee Valley Authority. 
[43] Ozmen, A., Notes to the concept of decentralization. European Scientific Journal, ESJ, 2014. 10(10).

[44] Raju, V. K., and Teron, A. (2019) River basin developments in India: An overview. Conference paper January 2019. Retrieved 05/08/2020 from https://www.researchgate.net/publication/330728233

[45] Reidinger, B. R. (2013) Comprehensive river basin development. The Tennessee Valley Authority. World Bank Technical Papers 12 AUG 2013. Retrieved 05/08/2020 from https://doi.org./10.1596/0-8213-4308-4

[46] Rostow, W. W. (1962) The stages of economic growth: a non-communist manifesto. Murray

[47] Printing Company Forge Village, Massachusetts, United States of America.

[48] Salem-Murdock, M. (1987) Hunger and river basin development in Africa: some socioeconomic issues. Geo-journal 14, 37 - 47 (1987)

[49] Sledge, D, and Mohler, G. (2013). Eliminating malaria in the American south:an analysis of the decline of malaria in 1930s Alabama American Journal of public health. Retrieved from http://www.nabi.nim.nih.gov.in Oct 20th 2019.

[50] Sorka, A.P (2007) Basic Theories in Administration and management Spectrum Books Street, E. (1981), "The Role of Electricity in TVA”. In: Saha S. K. and Barrows, C. J. Wiley. (eds) Basin Planning.New York. pp.233-252.

[51] Srinivasan, S. (1971), Regional economics.Bonday, Vora\& Co, Publishers Private Ltd., 1971, p.27

[52] Tungare, G. D. (1969) Some aspects of regional planning. Kurukshetre, VOL. 17 (March, 1969), p.6.

[53] Ugwu, S. D. and Kanu, I. (2012) Effects of Agricultural reforms on the agricultural sector in Nigeria. Journal of African Studies and Development Vol. 4(2), pp. 51-59, March, 2013.
[54] UNDP (1999) Decentralization: A sampling of definitions. Joint UNDPGovernmental Role in Decentralization and Local Governance, Working paper, October, 1999.

[55] UNCRD expert group meeting (2013). Integrated regional development planning. Nagoya, Japan: Nagoya.

[56] Vulkovic, D. and Kochetkov, D. M. (2017) Defining region. Journal. REconomy. DOI: 10.15826/recon.2017.3.2.009.

[57] World Bank (2001) Decentralization and subnational regional economics. Retirieved $\quad 09 / 08 / 2020 \quad$ from www.worldbank.org/publicsector/decentralization /admin.html

[58] Yamamura, E. and Masaaki, I. (1984) Regional planning in the Tennessee Valley: focus on the Transfer and Transformation of the TVA. Journal of the graduate School of environmental science, Hokkaido University, Sapporo, $7(1), 15-37$

\section{AUTHORS}

First Author - Ebifuro Odubo, Department of Geography and Environmental Management, Niger Delta University, Wilberforce Island, Bayelsa State.

Second Author - Eniye Mienye, Bayelsa State Polytechnic, Aleibiri, Bayelsa State 